\title{
Stress management in crisis event simulations for enhancing performance
}

Citation for published version (APA):

Ignacio, M. J. J. (2017). Stress management in crisis event simulations for enhancing performance. [Doctoral Thesis, Maastricht University]. https://doi.org/10.26481/dis.20170209mi

Document status and date:

Published: 01/01/2017

DOI:

10.26481/dis.20170209mi

Document Version:

Publisher's PDF, also known as Version of record

\section{Please check the document version of this publication:}

- A submitted manuscript is the version of the article upon submission and before peer-review. There can be important differences between the submitted version and the official published version of record.

People interested in the research are advised to contact the author for the final version of the publication, or visit the DOI to the publisher's website.

- The final author version and the galley proof are versions of the publication after peer review.

- The final published version features the final layout of the paper including the volume, issue and page numbers.

Link to publication

\footnotetext{
General rights rights.

- You may freely distribute the URL identifying the publication in the public portal. please follow below link for the End User Agreement:

www.umlib.nl/taverne-license

Take down policy

If you believe that this document breaches copyright please contact us at:

repository@maastrichtuniversity.nl

providing details and we will investigate your claim.
}

Copyright and moral rights for the publications made accessible in the public portal are retained by the authors and/or other copyright owners and it is a condition of accessing publications that users recognise and abide by the legal requirements associated with these

- Users may download and print one copy of any publication from the public portal for the purpose of private study or research.

- You may not further distribute the material or use it for any profit-making activity or commercial gain

If the publication is distributed under the terms of Article $25 \mathrm{fa}$ of the Dutch Copyright Act, indicated by the "Taverne" license above, 


\section{SUMMARY}


Chapter 1 contains the general introduction of the thesis. It describes the background, the rationale for undertaking the project, the aims and the research questions that this thesis addresses.

The clinical setting is replete with challenging clinical events that result in health professionals' experiencing stress. This is particularly true in clinical crisis events that happen acutely. As an emotional response, stress can affect the performance of clinical tasks and as a result, patient management. At right amounts, stress can result in competent performance of a clinical skill. At excessive amounts, however, it can impair performance such that patient management may be compromised. It was thus suggested that an emotional training strategy that addresses non-technical skills, such as stress management, is vital to health professions education. Simulation is increasingly being used as a platform to train health professionals in technical skills needed for future practice hence, the stress management strategy should be able to be seamlessly integrated into simulation training to meet its goals. By including such a strategy in training, it was expected that clinical performance will also be improved. There was a limited amount of literature in health professions education on how emotional training strategies, specifically stress management strategies, were used in healthcare simulation to train health professionals to reduce stress and improve performance during clinical crisis events. With this in view, we set out to determine the place of emotional training strategy in simulationbased learning of acute situations. To answer this, four main research questions were formulated:

1. What strategies are used to reduce trainees' stress during crisis event simulations and what is known about their effectiveness? 
2. What are the effects of using standardised patients versus highfidelity simulators on student performance and stress reduction?

3. What are the effects of a developed mental rehearsal strategy on student performance and stress reduction?

4. What are the effects of an improved mental rehearsal strategy integrated into simulations on student performance and stress reduction?

Chapter 2 partly answers the research question, "What strategies are used to reduce trainees' stress during crisis event simulations and what is known about their effectiveness?" It does so by firstly giving an overview of how health professionals are constantly exposed to stressors in the clinical environment, and how these stresses could affect patient safety and patient management. Secondly, this chapter demonstrates, the relationship between emotional responses, particularly stress and anxiety, and performance. Thirdly, it explains how the use of simulations could facilitate emotional training in nursing training guided by experiential learning. As experience is needed to learn and be proficient at any skill, it was also assumed that management of excessive stress could be developed through experience, particularly in highly realistic settings, such as in simulations. Finally, some of the strategies, such as mindfulness training, muscle relaxation and mental rehearsal that could be integrated into the nursing simulation training and curriculum to facilitate both skills and emotional training are expounded on.

The chapter closes by concluding that stress or anxiety are usually manifested by the nurses when they deal with high-acuity clinical events. Excessive stress and/or anxiety elicited during these critical hospital moments could impair performance and could result in detrimental effects 
on patient management and care. As there are already some strategies that have been used to reduce stress/anxiety in general settings, such as the ones mentioned in the preceding paragraph, the utilisation of any one or a combination of these could be integrated into the nursing curriculum, particularly in simulation training to reduce excessive stress/anxiety.

The research question, "What strategies are used to reduce trainees' stress during crisis event simulations and what is known about their effectiveness?" is further answered in Chapter 3. This chapter reports a literature review which was conducted to explore existing strategies used with simulations to enhance the ability of health professions trainees to reduce acute stress during high-acuity clinical events. This chapter explores the relative effectiveness of these strategies on stress management as these emotional responses can adversely affect performance during clinical crisis events. To address these aims, Scopus, PubMed, CINAHL, Web of Knowledge and Science Direct databases were searched. Peer-reviewed empirical papers that focused on the strategies addressing stress and/or anxiety during simulation training for healthcare professions' trainees were appraised. Only those papers written in the English language and published from January 2005 to March 2015 were included. The literature review findings highlighted in this chapter, shows eight studies using various forms of stress/anxiety management strategies with simulations. These studies demonstrated varying degrees of effectiveness in terms of stress and/or anxiety reduction. The themes that emerged from these eight studies, such as excessive stress and clinical performance in simulation, emotional training strategies in simulation, and factors contributing to stress and anxiety reduction during simulation, are further discussed in this chapter. Finally, from the discussions in this chapter, it was concluded that excessive stress and/or anxiety in the clinical setting truly affect 
performance and could compromise patient outcomes. Health professions training curricula, thus, might benefit from a stress/anxiety reduction strategy that could be integrated into their simulation programmes. We have also recommended that further studies need to be done to test the effectiveness of existing strategies in reducing stress and/or anxiety as the results pertaining to their effectiveness were equivocal. Furthermore, as most of them were conducted in surgical training, it would be valuable to see their usefulness in the training of other healthcare disciplines.

Chapter 4 answers the research question, "What are the effects of using standardised patients versus high-fidelity simulators on student performance and stress reduction?" It highlights a mixed methods study that compares the use of standardised patients (SPs) with high-fidelity simulators (HFS) in deteriorating patient simulations in terms of stress and performance. The use of SPs adds realism to a simulation scenario and this realism is thought to be valuable in preparing nurse trainees for stress and enhancing their performance during actual patient deterioration. In the control group design component of the study, where participants were randomised to either the SP group or the HFS group, pre- and post-tests were conducted to evaluate stress and performance in deteriorating patient simulations. Fifty-seven nursing students participated. Performance was assessed using the Rescuing A Patient in Deteriorating Situations (RAPIDS) rating tool. Stress was measured using salivary alpha-amylase levels. Fourteen participants from the randomised controlled component then participated in focus group discussions that elicited their insights on SP use in patient deterioration simulations. Using analysis of covariance (ANCOVA) results showed no significant difference, between the performance scores of the SP and HFS groups in managing deteriorating patients. Amylase levels were also not significantly different between the two groups. Three themes were 
generated from thematic analysis of the focus group discussions. The three themes are: stress in simulation, awareness of patient interactions, and realism. These themes suggest that the participants recognised the presence of stress in simulations, and that using SPs made them cognizant of the need to be aware of how they interact with patients. In addition, they found that the SPs added to authenticity to the clinical scenario.

The chapter further expounds on the possible reasons that led to the quantitative results, and gives a detailed explanation of the themes that emerged. It also proposes how the limitations of this study could be addressed in future research.

Chapter 4 concludes by acknowledging the contradicting results of the quantitative component and the focus groups component of the study. Although the control group design study showed no differences in stress and performance between the SP group and the HFS group, the focus group interviews for both groups suggested that the use of SPs had advantages over the use of mannequins in patient deterioration simulations as the former more closely mimicked real patient encounters. Potential advantages, however, need to be further explored, and its impact on actual clinical practice needs to be further investigated.

Chapter 5 underscores mental rehearsal (MR) as a form of mental training that has been successfully used by physicians and nurses to improve performance of clinical skills, and as a vital component of stress management training. This chapter describes the development, implementation and evaluation of an MR strategy that could be integrated into simulation to improve nursing students' clinical performance and stress management during critical clinical events, such as patient deterioration. To help novice nurses deal with often stressful clinical events 
that require the processing of information essential to patient management, this MR strategy was developed and implemented in a final year nursing simulation programme. Furthermore, a pre- and post-test design study participated in by 18 final year nursing students is described in this chapter.

The research question that this chapter addresses is, "What are the effects of a developed mental rehearsal strategy on student performance and stress reduction?" To answer this question, the quantitative study component used the RAPIDS rating tool to assess performance, and heart rates and systolic blood pressures, meanwhile, to measure stress. The State-Trait Anxiety Inventory (STAI), a psychological measure of stress/anxiety, was also used. The usefulness of the MR strategy was also qualitatively evaluated in this chapter using a focus group interview participated in by five nursing students who initially participated in the pre- and post-tests. The results reveal a significant improvement in performance between the pre and post-test scores. However, post-test heart rate and systolic blood pressure are not significantly different from pre-test measures. A comparison of STAI results did not show significant differences between pre- and post-test state anxiety and pre- and post-test trait anxiety. Managing stress, using a mental framework and integrating realistic simulations with the MR strategy are the themes that emerged from the qualitative analysis.

From the qualitative analysis, it was concluded that the participants perceived that the MR strategy has benefits in improving performance, thus supporting the findings of the pre- and post-tests. The MR strategy resulted in a significant improvement in performance scores during the post-test compared to the pre-test. Stress, nonetheless, remained unchanged. The 
strategy, therefore, has the potential to enhance student learning in simulation training, particularly in patient deterioration simulations. Future studies should look into developing it into a more robust strategy incorporated in realistic simulations to help enhance students' ability to translate theory to practice and promote patient safety.

In Chapter 6, a mixed methods study on an improved MR strategy which was developed, implemented and evaluated for final year nursing students in Chapter 5 is discussed. The central research question that this chapter tries to answer is, "What are the effects of an improved mental rehearsal strategy integrated into simulations on student performance and stress reduction?"

In this chapter, the MR strategy is implemented integrated into with simulations that utilise SPs. This chapter compares the effects of the MR in simulation strategy with the use of the airway, breathing, circulation, disability (ABCDE) mnemonic on the performance and stress levels of final year nursing students in assessing and managing patients in deterioration. The study featured in this chapter is a mixed methods design which consists of a randomised control group post-test followed-up by individual interviews. There were 32 final year nursing students who participated in the post-test. They were randomised to either the MR strategy in simulation (MR-SP) group or mnemonic (MM) group. Measures of performance used was the RAPIDS tool; stress measures were: the StraitTrait Anxiety Inventory (STAI), heart rate, systolic blood pressure, and skin temperature. There were 21 students who were interviewed individually as part of the qualitative component of the study after their nine-week clinical placement. This was to explore the students' views on the effects of the strategy on stress and performance in actual settings. There were no 
significant differences in performance scores between the MR in simulation group and the mnemonic group. The STAI, systolic blood pressure, heart rate, and skin temperature also were not significantly different. Three themes that emerged from the interviews indicated that the participants viewed the value of the MR strategy in simulation in the area of being mentally and emotionally prepared, recalling and visualising the steps to be taken, and enhancing actual clinical practice.

In conclusion, it was found that the $\mathrm{MR}$ in simulation and the mnemonic strategies had similar effects on performance and stress during patient deterioration management. The interviews, nonetheless, suggest that the MR strategy still benefits learning and could be used as an added strategy in other health professions' training. This chapter explores the possible reasons for study components' divergent findings, such as number of facilitated sessions, assessment-like nature of the post test, and lack of feedback when the MR strategy is done individually by students. Limitations of the featured study in this chapter are also discussed such that these could be addressed by future research.

In the final chapter, Chapter 7, the research questions posed in the beginning of this thesis are answered and elucidated. Furthermore, this chapter discusses how each of the scholarly work described from Chapters 2 to 6 are interconnected.

Based on the studies performed we conclude the following: (1) strategies used to reduce stress in simulations differ in terms of their effectiveness; (2) addition of SPs did not affect stress and performance measures but SPs have been perceived to add realism and prepare students for the actual clinical setting, showing its potential advantage in training for actual clinical practice; (3) the MR strategy showed promise only in 
improving performance despite its perceived positive effects on stress and performance, which suggest that a more robust MR strategy may in fact benefit learning, particularly of managing deteriorating patients; and (4) MR strategy integrated into simulations with SPs did not prove superior to the mnemonic strategy using mannequins, again despite positive student perceptions on the strategy, suggesting the need to further investigate the effects of the strategy on stress and performance in patient deterioration simulations.

The main implications of these studies to health professions education is the potential value of developing and constantly improving an emotional training strategy that could reduce stress and that could be integrated in simulations to train nurses, and eventually other healthcare professionals. Such a strategy could have vital effects on patient management and patient safety as stress could impair performance at excessive amounts. Suggestions on relevant future studies and how these studies could leverage on the findings extrapolated in this thesis are also described in Chapter 7. 


\title{
SAMENVATTING
}

\author{
Summary in Dutch
}


Hoofdstuk 1 geeft een algemene inleiding tot het proefschrift. Het beschrijft de achtergrond, de reden waarom we dit project ondernamen, de doelen en de onderzoeksvragen die in dit proefschrift worden beantwoord. In de klinische setting komen zorgprofessionals voor veel klinische uitdagingen te staan die hun stress bezorgen. Dit geldt vooral bij acute medische spoedgevallen. Stress, als emotionele reactie, kan de uitvoer van klinische taken en daarmee de behandeling van patiënten beïnvloeden. Gedoseerd kan stress leiden tot een adequate uitvoering van een klinische vaardigheid. Te veel stress kan de prestaties echter dusdanig verminderen dat de behandeling van patiënten in gevaar wordt gebracht. Daarom werd geopperd dat een emotionele trainingsstrategie gericht op het aanleren van niet-technische vaardigheden, zoals omgaan met stress, van essentieel belang is voor het gezondheidszorgonderwijs. Simulatie wordt steeds vaker aangewend als medium om zorgprofessionals de technische vaardigheden aan te leren die voor de toekomstige praktijk vereist zijn. De omgaan-metstressstrategie zou daarom eenvoudig voor zijn doeleinden in simulatietrainingen moeten kunnen worden ingebouwd. Door een dergelijke methode in de trainingen op te nemen verwachtten wij dat de klinische prestaties ook zouden verbeteren. Op het gebied van het gezondheidszorgonderwijs was er weinig literatuur beschikbaar over hoe emotionele trainingsstrategieën, in het bijzonder omgaan-metstressstrategieën, in zorgsimulaties werden gebruikt om zorgprofessionals te leren stress tijdens medische spoedgevallen te verminderen en prestaties te verbeteren. Met dit voor ogen, stelden we ons ten doel om de plaats van emotionele trainingsstrategieën in het leren van acute situaties door middel van simulatie te bepalen. Om dit te beantwoorden stelden we vier onderzoeksvragen op: 
1. Welke strategieën worden er gebruikt om stagiairs' stress te verminderen tijdens simulaties van spoedgevallen en wat is er bekend over hun effectiviteit?

2. Wat zijn de effecten van het gebruik van gestandaardiseerde patiënten ten opzichte van hoog-realistische simulatoren op de studentprestaties en stressvermindering?

3. Wat zijn de effecten van een ontwikkelde mentale oefeningsstrategie op de studentprestaties en stressvermindering?

4. Wat zijn de effecten van een in simulaties geïntegreerde, verbeterde mentale oefeningsstrategie op de studentprestaties en stressvermindering?

Hoofdstuk 2 geeft deels antwoord op de onderzoeksvraag "Welke strategieën worden er gebruikt om stagiairs' stress te verminderen tijdens simulaties van spoedgevallen en wat is er bekend over hun effectiviteit?". In de eerste plaats doet het dat door een overzicht te geven van hoe zorgprofessionals in de klinische omgeving continu aan stressveroorzakende factoren worden blootgesteld, en hoe deze spanningen de veiligheid en behandeling van patiënten kunnen beïnvloeden. Ten tweede toont dit hoofdstuk het verband tussen emotionele reacties, in het bijzonder stress en angst, en prestaties. Ten derde wordt uitgelegd hoe het gebruik van simulaties emotionele training in het verpleegkundeonderwijs aan de hand van ervaringsleren kan faciliteren. Aangezien ervaring nodig is om te leren en om welke vaardigheid dan ook te beheersen, gingen we ervan uit dat omgaan met te veel stress door ervaring kon worden ontwikkeld, vooral in hoogrealistische settingen, zoals bij simulaties. Ten slotte wordt een 
uiteenzetting gegeven van enkele strategieën, zoals mindfulnesstraining, spierontspanning en mentale oefening, die in simulatietrainingen en het curriculum van de verpleegkundeopleiding zouden kunnen worden opgenomen ter bevordering van zowel vaardigheden als emotionele training.

Het hoofdstuk sluit af met de conclusie dat stress of angst meestal bij verplegers de kop opsteekt wanneer zij met acute medische spoedgevallen te maken hebben. Als er tijdens deze kritieke ziekenhuismomenten te veel stress en/of angst wordt ervaren, zou dit de prestaties kunnen verminderen en nadelige gevolgen kunnen hebben voor de behandeling en zorg van patiënten. Aangezien er in algemene settingen al enkele strategieën worden toegepast om stress/angst te verminderen, zoals die in de vorige alinea werden genoemd, zou een willekeurige strategie of combinatie van deze strategieën ingebouwd kunnen worden in het verpleegkundecurriculum, in het bijzonder in simulatietraining, ter vermindering van te veel stress/angst.

De onderzoeksvraag "Welke strategieën worden er gebruikt om stagiairs' stress te verminderen tijdens simulaties van spoedgevallen en wat is er bekend over hun effectiviteit?" wordt verder beantwoord in Hoofdstuk 3. Dit hoofdstuk beschrijft een literatuuronderzoek dat we ondernamen om bestaande strategieën in kaart te brengen die bij simulaties worden toegepast om ervoor te zorgen dat stagiairs in de zorg beter in staat zijn om acute stress tijdens medische spoedgevallen te verminderen. Dit hoofdstuk onderzoekt de respectieve effectiviteit van deze strategieën wat betreft 
het omgaan met stress, omdat deze emotionele reacties de prestaties tijdens medische spoedgevallen nadelig kunnen beïnvloeden. Om dit doel te bereiken doorzochten wij de databases Scopus, CINAHL, Web of Knowledge en Sience Direct. Aan peer review onderworpen empirische artikelen die gefocust waren op strategieën voor de aanpak van stress en/of angst tijdens simulatietraining van stagiairs in de zorg werden beoordeeld. Alleen in het Engels geschreven en tussen januari 2005 en maart 2015 gepubliceerde artikelen werden geïncludeerd. De bevindingen van het literatuuronderzoek die in dit hoofdstuk worden belicht laten acht studies zien waarbij diverse vormen van omgaan-metstress/angststrategieën werden toegepast bij simulaties. Deze studies toonden diverse maten van effectiviteit wat betreft de vermindering van stress en/of angst. De thema's die uit deze acht studies naar voren kwamen, zoals te veel stress en klinische prestaties bij simulatie, emotionele trainingsstrategieën bij simulatie, en factoren die stress en angst helpen te verminderen tijdens simulatie, worden in dit hoofdstuk verder besproken. Uit de discussie in dit hoofdstuk werd uiteindelijk geconcludeerd dat een overmaat aan stress en/of angst in de klinische setting de prestaties inderdaad beïnvloedt en de patiëntenzorg in gevaar zou kunnen brengen. Curricula van opleidingen in de zorg zouden dus voordeel kunnen behalen als zij een stress/angstverminderingsstrategie in hun simulatieprogramma's opnamen. Gezien de tegenstrijdige resultaten met betrekking tot effectiviteit, was ons advies tevens om nader onderzoek te verrichten naar de effectiviteit van bestaande strategieën wat betreft stress- en/of angstvermindering. En ten slotte, aangezien de meeste strategieën werden toegepast in het chirurgisch onderwijs, zou het zinvol zijn om hun nut ook in het onderwijs van andere zorgdisciplines te onderzoeken. 
Hoofdstuk 4 geeft antwoord op de onderzoeksvraag "Wat zijn de effecten van het gebruik van gestandaardiseerde patiënten ten opzichte van hoogrealistische simulatoren op de studentprestaties en stressvermindering?". Het bespreekt een mixed-methodsstudie waarbij het gebruik van gestandaardiseerde patiënten (SP's) vergeleken wordt, qua stress en prestaties, met dat van hoog-realistische simulatoren (HFS*) bij simulaties van achteruitgaande patiënten. Het gebruik van SP's maakt een nagebootste situatie nóg echter, iets dat gezien wordt als waardevol voor de voorbereiding van verpleegkundestagiairs op stress en de verbetering van hun prestaties wanneer ze echt met een achteruitgaande patiënt te maken krijgen. In de controlegroepdesigncomponent van de studie, waar deelnemers willekeurig werden ingedeeld in ofwel de SP-groep dan wel de HFS-groep, verrichtten we

voor- en nametingen van stress en prestaties tijdens simulaties van achteruitgaande patiënten. Zevenenvijftig verpleegkundestudenten namen deel. Prestaties werden gemeten aan de hand van het Rescuing A Patient in Deteriorating Situations (RAPIDS)**-meetinstrument. Stress werd gemeten aan de hand van het alfa-amylasegehalte in speeksel. Veertien deelnemers uit het gerandomiseerde deel van het onderzoek met controlegroep namen vervolgens deel aan focusgroepgesprekken waarin er naar hun mening over het gebruik van SP's bij simulaties van achteruitgaande patiënten werd gevraagd. Uit de covariantieanalyse (ANCOVA) kwamen geen significante verschillen naar voren tussen de scores van de SP-groep en die van de HFS-groep op de manier waarop ze met achteruitgaande patiënten omgingen. De amylasegehalten van de twee groepen vertoonden ook geen significante verschillen. De thematische analyse van de focusgroepgesprekken leverde drie thema's op. De drie thema's zijn: “stress 
tijdens simulatie", "bewustwording van patiëntinteracties" en "realisme". Deze thema's geven aan dat de deelnemers de aanwezigheid van stress tijdens simulaties erkenden, en dat zij dankzij het gebruik van SP's inzagen hoe belangrijk het is dat zij zich bewust waren van de manier waarop zij met hun patiënten omgingen. Daarnaast vonden zij dat de SP's de echtheid van de nagebootste klinische situatie vergrootten.

Verder worden in het hoofdstuk de mogelijke redenen voor de kwantitatieve resultaten op een rijtje gezet en worden de gedistilleerde thema's uitgebreid toegelicht. Ook wordt voorgesteld hoe de beperkingen van deze studie door toekomstig onderzoek kunnen worden ondervangen. Hoofdstuk 4 wordt afgesloten met een erkenning van de tegenstrijdige resultaten van het kwantitatieve deel en het focusgroepdeel van de studie. Hoewel de studie met controlegroep geen verschillen liet zien in stress en prestaties tussen de SP-groep en de HFS-groep, gaven de focusgroepgesprekken met beide groepen aan dat het gebruik van SP's voordelen had ten opzichte van het gebruik van fantomen bij simulaties van achteruitgaande patiënten, omdat SP-gesprekken meer op échte patiëntgesprekken leken. Mogelijke voordelen, alsook de invloed daarvan op de werkelijke praktijk, moeten echter nog nader worden onderzocht.

In Hoofdstuk 5 ligt de nadruk op mentale oefening (MR***), d.w.z. een vorm van mentale training die succesvol door artsen en verpleegkundigen wordt gebruikt om de verrichting van klinische vaardigheden te verbeteren en die een onmisbaar onderdeel vormt van de training "omgaan met stress". Dit hoofdstuk beschrijft de ontwikkeling, invoering en evaluatie van een MR-strategie die in 
simulaties kan worden opgenomen om de klinische prestaties van verpleegkundestudenten en de manier waarop zij met stress omgaan tijdens kritieke klinische situaties, zoals een patiënt die in achteruitgaande toestand verkeert, te verbeteren. Om junior verpleegkundigen te helpen omgaan met klinische situaties die vaak stressvol zijn en waarbij zij informatie moeten verwerken die essentieel is voor de behandeling van de patiënt, werd deze MR-strategie ontwikkeld en in het laatste jaar van een simulatieprogramma binnen de verpleegkundeopleiding ingevoerd. Verder wordt in dit hoofdstuk een studie met voor- en nameting beschreven waaraan 18 laatstejaarsverpleegkundestudenten hebben deelgenomen.

De onderzoeksvraag die in dit hoofdstuk aan de orde komt is "Wat zijn de effecten van een ontwikkelde mentale oefeningsstrategie op de studentprestaties en stressvermindering?". Om deze vraag te beantwoorden werd in het kwantitatieve deel van het onderzoek gebruik gemaakt van het RAPIDS-meetinstrument om prestaties te beoordelen, terwijl stress bepaald werd aan de hand van hartslag- en systolische bloeddrukmetingen. Ook werd er gebruik gemaakt van de State-Trait Anxiety Inventory (STAI)-vragenlijst, een psychologisch instrument voor het meten van stress/angst op het niveau van de persoonlijke geneigdheid tot het ervaren van stress/angst en op het situatie-specifieke niveau. Het nut van de MR-strategie werd in dit hoofdstuk ook kwalitatief geëvalueerd door middel van een focusgroepgesprek met vijf verpleegkundestudenten die tevens aan de voor- en nametingen hadden deelgenomen. De resultaten laten een significante verbetering zien van de prestatiescores van de nameting ten opzichte van die van de voormeting. De hartslag- en systolische bloeddrukmetingen lieten echter geen significante verschillen zien tussen voor- en nameting. Een vergelijking van de STAI-resultaten liet 
geen significante verschillen zien tussen de voor- en nameting van situatiespecifieke stress/angst (state anxiety), noch van de geneigdheid tot het ervaren van stress/angst (trait anxiety). "Het omgaan met stress", "gebruik van een mentaal kader" en "integratie van realistische simulaties met de MR-strategie" waren de thema's die uit de kwantitatieve analyse naar voren kwamen.

Uit de kwalitatieve analyse werd geconcludeerd dat de deelnemers vonden dat de MR-strategie de prestaties kan verbeteren, waarmee zij de bevindingen van de voor- en nametingen staafden. De MR-strategie zorgde voor een significante verbetering van de prestatiescores op de nameting ten opzichte van de voormeting. Desondanks bleef het stressniveau onveranderd. De strategie is dus in staat het leren van studenten tijdens simulatietrainingen, en dan met name tijdens simulaties van achteruitgaande patiënten, te bevorderen. Toekomstige studies zouden moeten onderzoeken hoe zij verder ontwikkeld kan worden tot een meer gedegen strategie die onderdeel vormt van realistische simulaties, teneinde ervoor te zorgen dat studenten beter in staat zijn theorie naar de praktijk te vertalen en de patiëntveiligheid te bevorderen.

Hoofdstuk 6 bespreekt een mixed-methodsstudie over een verbeterde MR-strategie die in hoofdstuk 5 voor laatstejaarsverpleegkundestudenten was ontwikkeld, ingevoerd en geëvalueerd. De centrale onderzoeksvraag die dit hoofdstuk poogt te beantwoorden is "Wat zijn de effecten van een in simulaties geïntegreerde, verbeterde mentale oefeningsstrategie op de studentprestaties en stressvermindering?". In dit hoofdstuk wordt een MRstrategie ingevoerd als onderdeel van simulaties waarbij gebruik gemaakt 
wordt van SP's. Dit hoofdstuk vergelijkt de effecten van de MR-strategie in simulaties met die van het Airway, Breathing, Circulation, Disability, Exposure $(A B C D E)^{* * * *}$-ezelsbruggetje op de prestaties en stressniveaus van laatstejaarsverpleegkundestudenten tijdens het beoordelen en behandelen van achteruitgaande patiënten. De in dit hoofdstuk beschreven studie heeft een mixed-methodsdesign bestaande uit een gerandomiseerde controlegroep met nameting gevolgd door individuele interviews. Er waren 32 laatstejaarsverpleegkundestudenten die aan de nameting deelnamen. Zij werden willekeurig ingedeeld in ofwel de groep met de MR-strategie in simulatie (MR-SP-groep) dan wel de groep met het ezelsbruggetje (ABCDEgroep). Prestaties werden gemeten met behulp van het RAPIDSinstrument; het stressniveau werd bepaald op basis van de State-Trait Anxiety Inventory (STAI)-vragenlijst, en hartslag-, systolische bloeddruk- en huidtemperatuurmetingen. Er waren 21 studenten die individueel werden geïnterviewd na afloop van hun negen weken durende klinische stage ten behoeve van het kwalitatieve onderdeel van de studie. Hiermee probeerden we zicht te krijgen op wat studenten vonden van de effecten van de strategie op stress en prestaties in werkelijke settingen. Er waren geen significante verschillen in prestatiescores tussen de MR-SP-groep en de ABCDE-groep. De uitslagen van de STAI en systolische bloeddruk-, hartslag- en huidtemperatuurmetingen lieten ook geen significante verschillen zien. Drie thema's die uit de interviews naar voren kwamen toonden aan dat de waarde die de deelnemers aan de MR-strategie toekenden grotendeels neerkwam op "het mentaal en emotioneel voorbereid zijn", "het zich herinneren en voor zich zien van de te ondernemen stappen" en "het verbeteren van de werkelijke praktijk". 
Samenvattend waren onze bevindingen dat de MR-SP-strategie en de ABCDE-strategie ongeveer hetzelfde effect hadden op de prestaties en stress tijdens de behandeling van achteruitgaande patiënten. Desalniettemin duidden de interviews erop dat de MRstrategie het leren wel bevordert en ook voor andere opleidingen in de zorg een nuttige aanvulling zou kunnen zijn. In dit hoofdstuk wordt verder nog gezocht naar mogelijke redenen voor de afwijkende bevindingen, zoals het aantal begeleide sessies, het toetskarakter van de nameting en de afwezigheid van feedback wanneer studenten de MR-strategie individueel toepassen. De beperkingen van de in dit hoofdstuk besproken studie komen ook aan bod, zodat toekomstig onderzoek daar op kan letten.

In het laatste hoofdstuk, Hoofdstuk 7, worden de aan het begin van dit proefschrift gestelde onderzoeksvragen beantwoord en nader belicht. Verder bespreekt het hoofdstuk de samenhang tussen elk van de in hoofdstuk 2 tot en met 6 beschreven wetenschappelijke werken. Op basis van de uitgevoerde studies, concluderen we het volgende: 1) de effectiviteit van strategieën ter vermindering van stress tijdens simulaties verschilt per strategie, 2) toevoeging van SP's had geen invloed op stressniveaus en de prestaties, maar in de beleving van studenten vergrootten SP's de echtheid en bereidden zij hen voor op de werkelijke klinische setting, waarmee wordt aangetoond dat zij mogelijk van betekenis kunnen zijn in het opleiden voor de werkelijke praktijk, 3) de MR-strategie bleek alleen heil te bieden bij het verbeteren van de prestaties, ondanks dat studenten positieve effecten 
op stress en de prestaties ervaarden, wat erop duidt dat een meer gedegen MR-strategie het leren, met name van hoe om te gaan met achteruitgaande patiënten, wellicht kan bevorderen, en 4) simulaties met SP's waarin de MR-strategie was opgenomen bleken niet beter te zijn dan de mnemonische strategie waarbij gebruik werd gemaakt van fantomen, ook hier ondanks de positieve ervaring die studenten ermee hadden, wat erop wijst dat het effect van de strategie op stress en de prestaties tijdens simulaties van achteruitgaande patiënten nader onderzocht dient te worden.

De voornaamste gevolgen van deze studies voor het gezondheidszorgonderwijs is het inzicht dat het mogelijk waardevol is om een emotionele trainingsstrategie die stress zou kunnen verminderen en in simulaties kan worden opgenomen om verpleegkundigen en uiteindelijk ook andere zorgprofessionals op te leiden, te ontwikkelen en constant te verbeteren. Een dergelijke strategie zou essentiële gevolgen kunnen hebben voor de behandeling en de veiligheid van patiënten, omdat een teveel aan stress de prestaties kan verminderen. In hoofdstuk 7 wordt ten slotte nog een voorstel gedaan voor de koers van toekomstige studies en hoe zij het beste voort kunnen bouwen op de bevindingen die uit dit proefschrift voortvloeien.

* $\quad$ HFS = high-fidelity simulators

** Rescuing A Patient in Deteriorating Situations (RAPIDS): Het redden van een patiënt die in achteruitgaande toestand verkeert.

*** $\mathrm{MR}=$ mental rehearsal

**** Airway, Breathing, Circulation, Disability, Exposure = luchtweg, ademhaling, circulatie, bewustzijn blootstelling. 